Review

\title{
Pluripotent Core in Bovine Embryos: A Review
}

\author{
Luis Aguila ${ }^{1,2 *}$, Claudia Osycka-Salut ${ }^{3}$, Favian Treulen ${ }^{4}$ and Ricardo Felmer 1,2 \\ 1 Laboratory of Reproduction, Centre of Reproductive Biotechnology (CEBIOR-BIOREN), Universidad de La \\ Frontera, Temuco, Chile.; luis.aguila@ufrontera.cl. \\ 2 Department of Agricultural Sciences and Natural Resources, Faculty of Agriculture and Forestry Sciences, \\ Universidad de La Frontera, Temuco, Chile. \\ 3 Laboratorio de Biotecnologías Reproductivas y Mejoramiento Genético Animal, Instituto de Investigaciones \\ Biotecnológicas, Universidad Nacional de San Martín (UNSAM), Buenos Aires, Argentina.; cosycka@iib.un- \\ sam.edu.ar \\ 4 School of Medical Technology, Faculty of Science, Universidad Mayor, Temuco 4801043, Chile. \\ * Correspondence: luis.aguila@ufrontera.cl
}

Simple Summary: The fusion between sperm and oocyte results in a zygote, which is a single totipotent cell with the ability to develop into a functional organism. Totipotent cells can give rise to different specialized cell types from all lineages. Understanding the interactions between cell signaling pathways, which drive the early embryo to maintain pluripotency is essential to establish the optimal embryonic or stem cell culture conditions for biotechnological applications in cattle. Thus, this review summarizes the core of pluripotency genes, strategies for controlling the pluripotency and their potential applications on in vitro production of cattle embryos.

\begin{abstract}
Early development in mammals is characterized by the ability of each cell to produce a complete organism plus the extraembryonic, or placental, cells, defined as pluripotency. During subsequent development, pluripotency is lost, and cells begin to differentiate to a particular cell fate. This review summarizes the current knowledge of pluripotency features of bovine embryos cultured in vitro, focusing on the core of pluripotency genes (OCT4, NANOG, SOX2, and CDX2), and main chemical strategies for controlling pluripotent networks during early development. Finally, we will discuss the applicability of manipulating pluripotency during morula to blastocyst transition in cattle species.
\end{abstract}

Keywords: cattle, in vitro technologies, stem cells, IVF..

\section{Introduction}

The fusion between sperm and oocyte (two highly differentiated cells) results in a zygote, which is a single totipotent cell with the ability to develop into a functional organism. Totipotent cells can give rise to different specialized cell types from all lineages [1]. Accordingly, by early blastocyst stages mammalian embryos are characterized by two morphologically distinct cell populations: outer and inner cells in the morula form the surrounding trophectoderm (TE) and the inner cell mass (ICM), respectively, during blastulation. The ICM is formed by totipotent embryonic stem cells (ESCs) that later (in a second wave) differentiates into the pluripotent epiblast (EPI, the nascent embryo proper) and the primitive endoderm ( $\mathrm{PrE})$, in non-rodent mammals identified as the hypoblast (HP). The TE, on the other hand, is the precursor of the placenta and the first component of the extraembryonic structures [2,3]. In bovines, many genes show differences in expression between ICM and TE that differs from that observed in mouse or human species [4]. The lineage specification in cattle seems to be directed by a different set of regulatory factors [5]. Moreover, the precise molecular interactions governing ICM/TE specification in this species has not been totally clarified yet [6]. Thus, understanding the interactions between cell signaling pathways, which drive the ICM to maintain pluripotency is essential to establish the optimal embryonic or stem cell culture conditions for biotechnological ap- 
plications [4]. For instance, bovine embryos with low development potential show precarious balance between pluripotency factors that disturbs later stages of embryonic development [7]. In cattle, the lineages become fully segregated at the late blastocyst stage [5], where the triad of genes OCT4, NANOG and SOX2 are critical transcription factors related to pluripotency maintenance in the ICM, and together with $C D X 2$ are essential for early development and gene expression involved in differentiation of ICM and TE lineages[8].

Thus, this article focuses on three main topics restricted to bovine species. We will review literature describing pluripotency features of bovine embryos cultured in vitro, focusing on the core of pluripotency genes (OCT4, NANOG, SOX2, and CDX2), and main chemical strategies for maintaining a pluripotent state during early development. Finally, we will discuss the applicability of inducing or maintaining pluripotency in vitro.

\section{Pluripotent core in early bovine development}

\subsection{OCT4 (POU5F1)}

OCT4 is a transcription factor that belongs to the POU transcription family domain (POU5F1), which is expressed predominantly in pluripotent cells [9]. In bovines, OCT4 acts as regulator of CDX2 expression and trophectoderm specification [10,11], as well as in the transition of polar and mural trophoblast development [12]. Moreover, the transcriptional profile of OCT4 in the bovine embryo does not follow the same pattern of the mouse ortholog. The first studies found that bovine blastocysts expressed OCT4 mRNA only in the ICM and its presence in the TE would be the cause of a high stability of the protein or due to a delay in its clearance [13]. However, other authors have found that its expression is not restricted to pluripotent cells and therefore it can be found in both, ICM and TE cells [7,14-16].

During development, the maternal-derived OCT4 transcript is present in the bovine oocyte but after fertilization a decrease in its abundance is observed until the time of embryonic genome activation (EGA), and then it increases significantly after the morula stage $[7,10,13,17,18]$. In OCT4-KO morulae (day 5), $70 \%$ of the nuclei were OCT4 positive, indicating that maternal transcripts can partially maintain OCT4 expression during early development [11]. At the morula stage, OCT4 and CDX2 proteins show global nuclear localization $[7,19]$. Interestingly, presence of OCT-4 and NANOG in the TE does not interfere with the expression of trophoblast-specific genes, such as CDX2 or interferon tau (IFN-T) [12]. Moreover, it is not possible to increase OCT4 expression by decreasing CDX2, indicating that in opposite to mice, bovine OCT4 is no regulated by CDX2 [11,20]. One of the authors speculated that bovine TE is regulated by different factors and/or the regulatory region of OCT4 gene show variations between species [20]. Besides, the presence of OCT4 in the TE correlates with a lack of commitment of this tissue to conserve the plasticity of a "non-differentiating trophoblast" [12].

Because the process of ICM-specific allocation is gradual, OCT4 can be found in both, the ICM and in surrounding TE cells of early blastocysts (7 days post fertilization [dpf]). At 8-9 dpf OCT4 positive blastomeres are predominantly located in the ICM, however it is still detected within the TE cell population $[7,19]$, where expression of OCT4 and CDX2 did not differ between ICM and TE [4]. After blastocyst hatching or $9 \mathrm{dpf}$, OCT4 is located exclusively in ICM cells $[17,19,21]$.

OCT4 contributes to maintaining cells in an undifferentiated state by modulating expression of different loci involved in pluripotency and cellular differentiation [22]. Besides, OCT4 acts as regulator of cell lineage specification beyond the morula stage and is necessary for pluripotency maintenance and NANOG expression [11]. For instance, silencing of IFNT involves quenching of the transactivation site to inhibit differentiation towards the trophectoderm [23]. The disruption of OCT4 gene affects blastulation but not the ability of embryos to progress up to the morula stage, suggesting that OCT4 is not required for cell proliferation after EGA $[8,10]$. Although the absence of OCT4 expression decreases the number of ICM cells and embryonic quality [24], other authors have observed that embryos with different developmental potential, such as those produced by 
SCNT, in vivo-derived and IVF embryos have similar levels of OCT4 expression [25]. In same line, parthenogenetic embryos having a reduced expression of OCT4 showed no reduced cell counts, suggesting that a reduction in OCT4 expression could be not always limitative of the ICM viability [26]. Thus, OCT4 transcripts are indicative of pluripotency but would not be considered as a specific marker for embryo quality.

\subsection{NANOG}

NANOG (Homeobox protein NANOG) is a member of the homeobox family of DNA binding transcription factors that is known to maintain the pluripotency of ESCs [27]. In the bovine embryo, NANOG expression begins at 8-16 cell stage, which is the time of major EGA $[7,19]$. Although transcripts for NANOG are detected in 5-cell and 8-16 cell stage embryos, the protein is not detectable at these stages [28]. Instead, it appears de novo at the morula stage and cavitating embryos as a product of the embryonic genome, mainly from the nascent ICM $[7,19,28]$. In early blastocysts (7 dpi) NANOG is also located in both, the ICM and in the surrounding TE cells[29,30]. After hatching, NANOG become exclusively ICM specific $[5,17,19,28,31]$, which has been confirmed by RNA sequencing approaches $[4,17,32]$. Within the group of cells expressing OCT4 and NANOG, there are cells expressing only NANOG and other expressing both factors, with NANOG protein being predominantly nuclear and OCT4 nuclear and cytoplasmic [19].

Functionally, NANOG is not required for proper segregation of TE and ICM, but it is required to derive and maintain the pluripotent epiblast and during the second lineage commitment [33,34]. Moreover, it seems to be implicated in cell proliferation, probably depending on FGF4 signaling (also involved in fate decision and patterning events in the early embryo) from EPI precursor cells [33]. Thus, disruption of NANOG gene did not affect blastocyst rate but resulted in reduced total cell number [33] and an ICM composed mostly of hypoblast cells [34]. In the nascent epiblast, NANOG mediated repression of hypoblast markers, such as SOX17, which is dependent on MEK signaling, but FGF4-induced expression of SOX17 depends on NANOG, therefore the establishment of hypoblast lineage depends on epiblast mediated FGF/MEK signaling [33]. In relation to other markers, absence of NANOG resulted in lower expression of the epiblast cell marker SOX2, and hypoblast marker GATA6; without affecting the trophectoderm [34]. Moreover, in bovines, the activation of NANOG might be OCT4 related. Simmet et al. [11] showed that although OCT4-KO bovine blastocysts expressed NANOG at the morula stage (probably remains of maternal origin), it was depleted in later stages, suggesting that NANOG expression is mutually regulated with OCT4 [11] (Figure 1).

\subsection{SOX2}

SRY (sex determining region Y)-box 2, also known as SOX2, is a transcription factor that is essential for maintaining self-renewal, and pluripotency and has been reported as highly expressed in bovine ESCs [35].

During early development, SOX2 is present in the germinal vesicle and metaphase II (MII) oocyte stages, and it can persist in nuclear and cytoplasmic compartments of 4 and 8 cell embryos [7,36,37]. Expression of SOX2 in all nuclei continues in both human and cow embryos up to the formation of an early blastocyst [38]. At the 8-cell stage it is coexpressed with NANOG, but at the blastocysts it overlaps with NANOG and GATA6 in the ICM $[5,17,36]$. Although it is restricted to ICM $[4,35]$, recently confirmed by RNA sequencing approaches $[4,17,32]$, some embryos can also show a weak SOX2 expression in TE cells $[5,17,36]$. This weak presence of SOX2 in the bovine trophoblast could also argue for a delayed commitment of TE cells to differentiate [12,20].

SOX2 is necessary for maintaining the undifferentiated state of the bovine ICM [32]. Lacking SOX2 resulted in blastocyst with a reduced number of blastomeres associated with poor embryonic quality[39-41], indicating a role in cell proliferation. Similarly, the knockdown of SOX2 led to the formation of a blastocyst with reduced expression of NANOG, since absence of NANOG results in lower expression of SOX2, this suggests a 
mutual regulation between SOX2 and NANOG [34,42,43] (Figure 1). Remarkably, disruption of OCT4 did not affect expression of SOX2, suggesting that initiation of ICM formation is OCT4-independent [10]. In addition, unbalanced overexpression of SOX2 showed negative effects on the control of embryonic developmental potential [44]. Dysregulated expression of OCT4 and SOX2 in cloned blastocysts has been also related to a low developmental competence in cattle [45-47]. Thus, SOX2 plays a key role in formation, maintenance, and plasticity of the ICM compartment, and therefore, on embryonic quality.

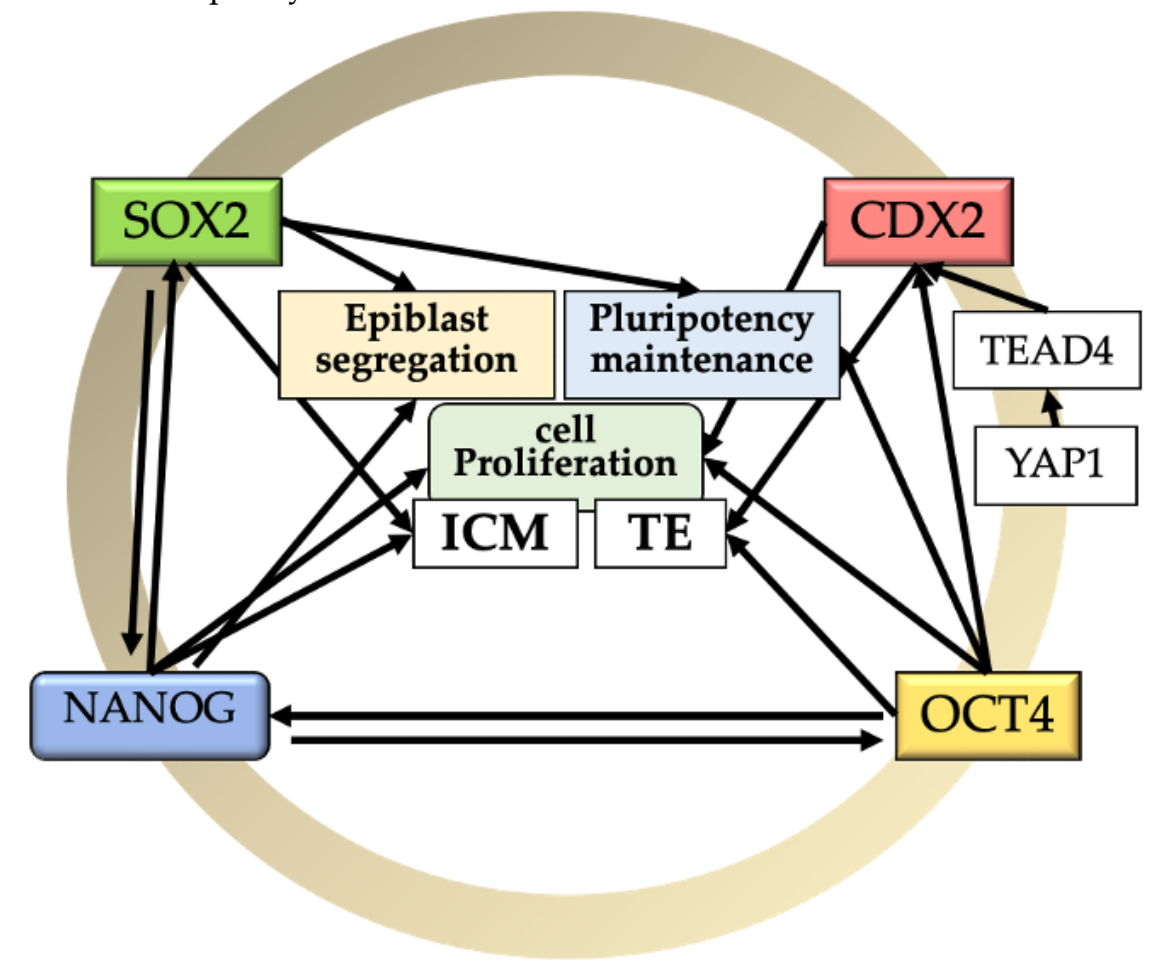

Figure 1. Relationship among core of pluripotency factors and epiblast segregation, pluripotency maintenance and cell proliferation during early bovine development. SOX2: SRY (sex determining region Y)-box 2; OCT4: POU5F1; NANOG: Homeobox protein NANOG. Black arrows indicate a positive correlation.

\subsection{Homeobox protein $C D X 2$}

CDX2 is the master regulator of TE lineage specification $[10,20,28,42,48,49]$. CDX2 transcript is present in oocytes but it decreases gradually after fertilization [48]. CDX2 protein is found in the cytoplasm of all cells of a 5-cell embryos, but at the subsequent stages, it is found into the cell nuclei [19]. CDX2 is present at the time of major EGA (8-16 cell-stage) and increases afterward from morula to blastocyst stage $[10,19,20,28,42,49]$. At $7-8 \mathrm{dpf}$ CDX2 segregation to the trophoblast cells can be noted, however a weak signal is still present within the ICM cells during the time from expanded to hatched blastocysts $[19,20,48]$. At more advanced developmental stages, after $9 \mathrm{dpf}$ CDX2 level is at least 3-fold higher in the TE than the ICM [19]. Particularly, CDX2 transcripts start exceeding OCT4 in the TE after hatching around day 9 [20]. Moreover, OCT4 is not required to suppress CDX2 in the bovine ICM [11]. Although it has been reported that CDX2 overexpression downregulated OCT4 [49], others have observed that OCT4 expression was unaffected by CDX2 downregulation, and the deletion of the OCT4 gene did not affect CDX2 expression in the bovine TE [11,42], ruling out a mutual regulation (Figure 1).

In mice, specification of the TE lineage from the pluripotent early blastomeres involves the Hippo signaling pathway with activation of CDX2 and TEAD4 (another transcription factor) playing a decisive role [50,51]. Similarly, TEAD4 transcript is present at the morula stage in the bovine [20], which would activate CDX2 to establish TE lineage 
[5]. A recent study confirmed that ICM of bovine possess the potency to become TE through the YAP1-TEAD4 axis [52]. Thus, although TE cells of the late expanded blastocyst are prone to remain trophectoderm, they are not yet committed to this fate [20,52].

At genetic level, CDX2 regulates multiple trophoblast genes such as IFNT, HAND1, ASCL2, SOX15, and ELF5 [17,49], and it is important to maintain integrity and proliferation of the trophoblast tissue [8]. Interestingly, CDX2-Knockdown (CDX2-KD) blastocysts formed normal blastocoel cavity, cell number and allocation, and hatched normally without affecting OCT4, NANOG and SOX2 [48]. Besides, the absence of CDX2 promoted the overexpression of TEAD4, probably as compensatory mechanism. Therefore, expression of TEAD4 may contribute to regulate bovine blastocysts formation along with CDX2 [48].

In summary, CDX2 is key regulator/inducer for formation and functional maintenance of TE. It is expressed during the whole period of blastocyts development and localized on TE and ICM of bovine embryos.

\section{Chemical modulation of pluripotency in early bovine development}

\subsection{WNT (wingless-related mouse mammary tumor virus) pathway}

The WNT signaling pathway is a well-known evolutionary and conserved pathway that regulates crucial aspects of cell fate determination and embryonic development [53]. In cattle, there are several studies reporting contrasting effects of the activation/inhibition of WNT signaling during the early period of embryonic development (Figure 2, Table 1). One study showed that the activation of WNT signaling by blocking glycogen synthase kinase (GSK3) activity with $\mathrm{LiCl} 2$ or CT99021 had inconsistent effects on development to the blastocyst stage. $\mathrm{LiCl}$ decreased the proportion of zygotes reaching the blastocyst stage, while CT99021 increased the development [54]. Later, the study of Kuijk et al [28] showed that embryos treated from the zygote to the blastocyst stage in the presence of the GSK3 inhibitor CHIR99021 at $3 \mu \mathrm{M}$ had higher percentage of NANOG cells in the ICM. In addition, when the GSK3 inhibitor was present from the morula stage onwards they did not see effects on ICM constitution [28]. Denicol et al [40] observed that activation of canonical WNT signaling with the agonist AMBMP from day 5, disturbed the development until blastocyst stage and reduced the number of TE and ICM cells. This is not surprising since this molecule also disrupts microtubule organization [55]. Another study observed that blocking GSK3 with CHIR99021 (3 $\mu \mathrm{M})$ from morula stage onwards improved blastocyst morphology and epiblast-specific gene expression (NANOG, SOX2) [56]. Similarly, Madeja et al [9] indicated that WNT activation with CHIR99021 increased the expression of OCT4 and NANOG in the ICM, and downregulated CDX2 expression. Meng et al [31] used forskolin which activates adenylate cyclase and cAMP/PKA signaling pathway, in turn inactivating GSK3 and thus acting synergistically with WNTs. Forskolin increased three-fold NANOG expression [31]. More recently, Warzych et al [5] also observed that WNT signaling (activated by CHIR99021) increased the levels of NANOG and OCT4 transcripts and NANOG positive cells within the ICM. Also, the proportion of OCT4 positive cells increased in the TE, concomitant with the downregulation of CDX2 [5]. Likewise, Sidrat et al [57] used 6 bromoindurbin-3'oxime (6-Bio) as a WNT agonist, observing a higher expression of peroxisome proliferator-activated receptor-delta (PPARS) which colocalized with Beta-CATENIN and formed a complex with TCF/LEF transcription factor. In addition, 6-Bio enhanced the expression of Beta-CATENIN, OCT4, AXIN2 and C-MYC, but CDX2 was downregulated. Moreover, the inhibition of PPAR $\delta$ with Gsk3787 severely perturbed blastocyst formation and hatching, suggesting an important role for PPARठ as candidate of regulation of canonical WNT pathway. 

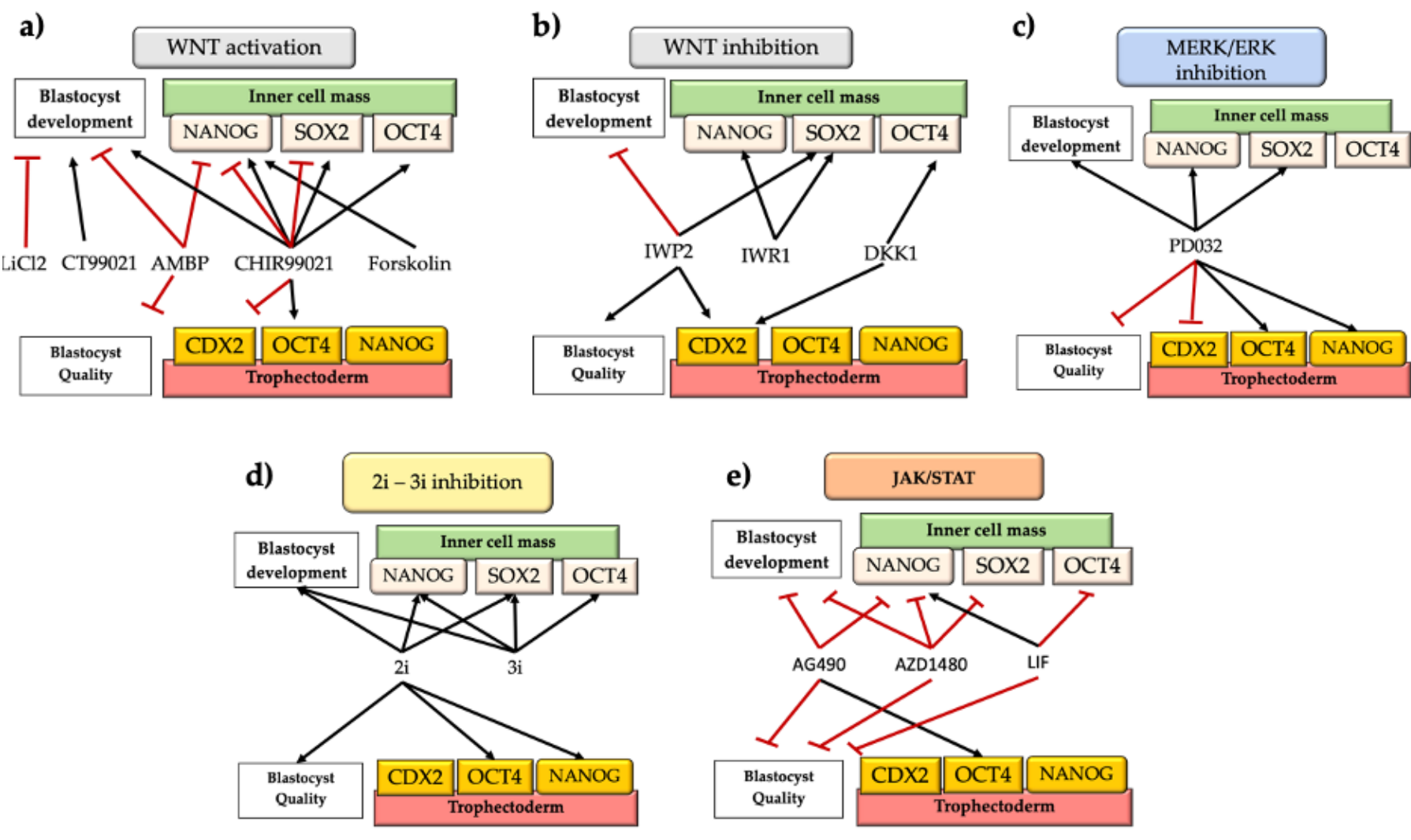

Figure 2. Effects of small molecules on levels of pluripotency factors (NANOG, SOX2, OCT4 and CDX2), embryonic development, and quality according to total cell number. It is noted that some molecules have shown opposites effects across the literature reviewed. SOX2: SRY (sex determining region Y)-box 2; OCT4: POU5F1; NANOG: Homeobox protein NANOG. CDX2: Homeobox protein CDX2. WNT: wingless-related mouse mammary tumor virus pathway; MEK/ERK: mitogen-activated protein kinase pathway. JAK/STAT: Janus kinases and activator of transcription proteins pathway. Black arrows indicate a positive correlation, and red lines indicate a negative correlation.

On the other hand, other authors have indicated that inhibition of canonical WNT signaling regulates blastocyst development and its quality. For instance, Denicol et al [58] found that the WNT antagonist DKK1 added from morula to blastocyst stage promoted differentiation of cells towards trophectoderm and hypoblast lineages [58]. Similarly, exposure to Wnt-C59, which blocks secretion of WNTs, or DKK1, and interferes the activation of the WNT-FZD-LRP5/6 receptor complex, did not affect development, but Wnt-C59 increased the number of ICM cells, suggesting that regulation of ICM proliferation by endogenous WNTs is independent of the canonical signaling [41]. However, recently was showed that inhibition of canonical WNT signaling by using IWR1-inhibitor was crucial for ICM proliferation and derivation of bovine ESCs [35]. Another study indicated that the WNT-inhibitor IWP2 increased the total cell number in blastocysts by increasing the number of TE cells and the number of NANOG positive cells within the ICM but decreasing the percentage of blastocysts [36]. The differences among previous studies could be due to the different specificity and efficacy of the WNT inhibitors used [36]. In fact, recently Xiao et al [39] evaluated the effects of different WNT inhibitors on the derivation efficiency of bovine ESCs. They found that canonical WNT signaling was antagonist to pluripotency and derivation of pluripotent bovine ESCs involved inhibition of WNT signaling.

Nonetheless, not all inhibitors showed the same efficacy, with IWR-1 and IWP2 being effective unlike XAV939 and DKK1. In addition, it was observed that IWR1-inhibition between day 4 to 7.5 after fertilization blocked activation and differentiation into a 
pSTAT3+lineage. In the mouse embryo, Stat3 induces differentiation towards the TE lineage when its activation level exceeds certain thresholds [59]. Furthermore, CHIR99021 depressed expression of both NANOG and SOX2 in bovine ESCs and decreased number and percent of blastomeres positives for NANOG and SOX2 in the embryo [39]. In this line, other studies indicate that TE cells highly express transcripts related to WNT signaling [21,32], as observed that activation of WNT signaling enable the derivation of trophoblast stem cell by regulating CDX2 expression through the WNT-YAP/TAZ signaling pathway [60].

Overall, the data indicate that the effects of WNT activation/inhibition will depend on the specificity of the inhibitor and time of exposure. In addition, WNT signaling plays a role on TE specification and the use of specific inhibitors able to interact with JAK and WNT signaling pathways enable the induction of epiblast pluripotency in the blastocyst.

\subsection{MEK/ERK PATHWAY}

Molecular interactions of signaling pathways like MEK/ERK and WNT/b-catenin are critical for cell-to-cell communication and cellular differentiation. Secreted uterine FGF factors induce lineage commitment by activating the mitogen-activated protein kinase (MAPK), comprising MAPK kinase 2 (MAP2K, also known as MAPKK or MEK) and MAPK1/2 (ERK). It is reported that FGF4 mRNA is present in the trophectoderm of spherical bovine blastocysts [12]. FGF4 can induce the formation of hypoblast and block the formation of epiblast precursors [28], but the role of FGF4 in bovine embryo development differs from the observations in mouse, since FGF4 and MAPK signaling is not essential for bovine hypoblast specification [28].

The suppression of MEK signaling by PD98059 or PD325901 has been performed in numerous studies to detect the importance of MEK/ERK signaling in early development in bovines although with controversial outcomes. Inhibition of MEK in bovine embryos resulted in ICM with increased epiblast precursors (NANOG+) and decreased hypoblast precursor (GATA6) [28]. Blocking bovine MEK with PD0325901 (0.4 ๑ M) was also correlated with improvement on blastocyst morphology and increases of epiblast-specific gene expression (NANOG, SOX2) [56,61]. In addition, trophoblast proliferation, lineage specification, and blastocyst formation were not affected [56,61,62]. This is consistent with studies showing that isolated trophoblast cells did not require an active FGF/MEK signaling to survive, proliferate, and maintain $C D X 2$ expression [61,63-65]. In agreement with Kuijk et al [28], under MEK inhibition (PD0325901 0.5 and $2.5 \odot \mathrm{M}$ ) the embryonic development or cell numbers were not affected but the proportion of NANOG positive cells was markedly increased, while the expression of GATA6 was reduced but not completely switched off [33].

The effects of MEK inhibition seem to be dose-dependent [5,36]. The study of Canizo et al [36] indicated that MEK inhibition does not promote epiblast fate, but rather prevents hypoblast segregation in cattle. MEK inhibition with PD0325901 at $0.4 \mu \mathrm{M}$ decreased the numbers of ICM cells, but it has a trophic effect on TE. Instead, high concentrations of MEK inhibition (between 1 and $2 \mu \mathrm{M}$ ) resulted in abolition of hypoblast segregation and $10 \mu \mathrm{M}$ affected both, TE and ICM compartments [36]. Similarly, another study indicated that MEK/ERK downregulation (PD0325901, $1 \mu \mathrm{M}$ ) maintained OCT4 and NANOG within the ICM and prevents their exclusion from the TE, but CDX2 was downregulated [5].

\subsection{The use of $2 i$ and $3 i$ in early bovine embryonic development}

Both these systems operate within the WNT and the MEK/ERK signaling pathways but use a different set of inhibitors. The 3i system consists of MEK/ERK inhibition (PD184352), FGF receptor inhibitor (SU5402) and GSK3 inhibitor (CHIR99021). The first two inhibitors are involved in the suppression of the MAPK/ERK pathway, whereas the inhibition of GSK3 supports the WNT activity. The 2i system includes CHIR99021 and MEK inhibition (PD0325901) [66]. 
Early studies found that the double inhibition (2i) of MEK and GSK3 offered defined culture conditions for blocking exit from pluripotency. The use of $2 \mathrm{i}$ enhanced bovine blastocyst development and expression of epiblast NANOG and SOX2 markers by reducing expression of the hypoblast marker GATA4 [56]. Presence of $2 \mathrm{i}(0.4-10$ ๑ $\mathrm{M})$ from the morula stage (D5) onward increased the numbers of ICM cells, but NANOG and FGF4 were up regulated and segregation to hypoblast was reduced in the ICM after exposure to $3 \mathrm{i}$ combinations [61]. From day 2 onward, 3i improved embryonic development affecting ICM-related genes (OCT4, SOX2 and NANOG)[29]. However, others authors only found positive effects of $2 \mathrm{i}$ on blastocyst quality according to total cell and ICM number [66]. Similarly, Warzych et al [5] observed higher levels of epiblast-related genes (NANOG and OCT4) under $2 \mathrm{i}$ system, but without affecting the number of cells in the blastocyst. Likewise, Kuijk et al [28] did not find any synergetic effects between CHIR99021 and PD032590, as recently indicated that modulation of WNT is not sufficient to support enhanced NANOG expression in the epiblast when combined with ERK inhibitor [36] (Figure 2, Table 1).

Additionally, these pathways seem to be involved in regulation of apoptosis. The study of Madeja et al [66] found positive effects of 2i on ICM constitution, however total cell count in $3 \mathrm{i}$ cultured embryos was reduced. Besides, embryos cultured under $2 \mathrm{i}$ or $3 \mathrm{i}$ systems showed a higher rate of apoptosis and lower embryonic quality but without changes in $B A X, B C L 2$, and $B A K$ transcripts, suggesting alternative pathways involved on this apoptotic activation.

\subsection{JAK/STAT}

In the study of Meng et al [31], the authors observed that chemically suppressing JAK/STAT signaling (via JAK2/3) with AG490 and JAK1/2 inhibition with AZD1480 strongly compromised blastocyst development, quality and ICM numbers without affecting the TE. In addition, NANOG was reduced with both AG490 and AZD1480 treatments. The latter also strongly reduced SOX2, KFL4, FGF4 and hypoblast markers (SOX17, PDG$F R \alpha$ ), without affecting CDX2. In addition, phosphorylation of STAT3 tyrosine (Y) 705, which is related to JAK1 pluripotency-signal [67], co-localized with NANOG and SOX2 within the ICM in D7 and D8 blastocysts [31], suggesting its role on ICM specification (Figure 2, Table 1).

On the other hand, locally secreted FGF4 can activates both i) mitogen-activated protein kinase (MAP2K) and ii) phosphatidylinositol 3- kinase (PI3K)-AKT [5,31,68]. JAK/STAT activation is also triggered by Leukemia inhibitory factor (LIF) and related members of the interleukin (IL) family. In bovines, LIF added to the culture medium from 4-cell did not show a significant beneficial effect [69]. However, when added to the culture medium from Days 5 to 8 showed adverse effects on in vitro embryonic development based on kinetics, morphology, cell count as well as the expression of OCT4 [70]. Similarly, others authors indicate that LIF does not affect trophoblast and ICM cell numbers [71], or do not observe detrimental effects on blastocyst development that might be result of the antimitotic effect of LIF especially when used in early cleavage stages [72]. Recently, Canizo et al [36] reported that LIF added to $2 \mathrm{i}$ cocktail boost the blastocyst yields, and LIF alone promoted expansion of hypoblast in bovine embryos, suggesting that LIF has embryotropic effects in the ICM by increasing NANOG and SOX17 markers. Thus, JAK/STAT signals are required for bovine ICM formation and acquisition of pluripotency markers. 
Table 1. Different molecules and their effects on factors related to pluripotency and embryonic development in cattle.

\begin{tabular}{|c|c|c|c|c|c|c|}
\hline Reference & $\begin{array}{l}\text { Days in } \\
\text { culture }\end{array}$ & Molecule & Effect & Concentration & Effects on pluripotency-related factors & Effects on early development \\
\hline \multicolumn{7}{|l|}{ 1. WNT pathway } \\
\hline $\begin{array}{l}\text { Kuijk et al., } \\
2012\end{array}$ & day $1-8$ & Chir99 & $\begin{array}{l}\text { WNT } \\
\text { activation }\end{array}$ & $3 \mu \mathrm{M}$ & $\begin{array}{c}\text { Slightly higher percentage of NANOG-positive cells than } \\
\text { control embryos. Moreover, no synergistic effect } \\
\text { between Chir99 and PDO32. Induced specification of } \\
\text { hypoblast markers }\end{array}$ & N.D. \\
\hline $\begin{array}{l}\text { Harris el al., } \\
2013\end{array}$ & $\begin{array}{l}\text { day } 5 \\
\text { onward }\end{array}$ & Chir99 & $\begin{array}{l}\text { WN'l' } \\
\text { activation }\end{array}$ & $3 \mu \mathrm{M}$ & Increase coll numbers in the TE and ICM. & N.D. \\
\hline $\begin{array}{l}\text { Denicol et al., } \\
2013\end{array}$ & $\begin{array}{l}\text { day } 5 \\
\text { onward }\end{array}$ & AMBMP & $\begin{array}{l}\text { WNT } \\
\text { activation }\end{array}$ & $0.7-2.8 \mu \mathrm{M}$ & Reduced the number in the TE cells and ICM & $\begin{array}{l}\text { Affected the development unti] } \\
\text { blastocyst stage }\end{array}$ \\
\hline $\begin{array}{l}\text { Madcja el al., } \\
2015\end{array}$ & day $1-9$ & Chir99 & $\begin{array}{l}\text { WN'l' } \\
\text { activation }\end{array}$ & $3 \mu \mathrm{M}$ & $\begin{array}{l}\text { Higher expression of OCT4 and NANOG in the ICM } \\
\text { and the TE, but not accompanied by an increase of cell } \\
\text { number positive for NANOG. Downregulation of CDX2 } \\
\text { expression in the TE. GATA6 significantly upregulated. } \\
\text { Induced specifica tion of hypoblast markers }\end{array}$ & N.D. \\
\hline $\begin{array}{l}\text { Meng cl al., } \\
2015\end{array}$ & $\begin{array}{l}\text { day } 5 \\
\text { onward }\end{array}$ & Forskolin & $\begin{array}{l}\text { WNT } \\
\text { activation }\end{array}$ & $10 \mu \mathrm{M}$ & $\begin{array}{l}\text { Increased NANOG expression threc-fold withoul } \\
\text { significantly altering FGF4 or hypoblast markers }\end{array}$ & N.D. \\
\hline \multirow{5}{*}{ 'Iribulo el al., 20} & \multirow{5}{*}{$\begin{array}{l}\text { day } 5 \\
\text { onward }\end{array}$} & AMBMP & $\begin{array}{l}\text { WNT } \\
\text { activation }\end{array}$ & $0.7 \mu \mathrm{M}$ & Induced accumulation of $\beta$-CATENIN & $\begin{array}{l}\text { Reduced development to the } \\
\text { blastocyst stage }\end{array}$ \\
\hline & & Wnt-C59 & $\begin{array}{l}\text { WNT } \\
\text { activation }\end{array}$ & $10 \mu \mathrm{M}$ & Induced a coumulation of $\beta$-CATENIN & $\begin{array}{l}\text { Decreased the proportion of } \\
\text { oocytes and cleaved embryos } \\
\text { becoming blastocysts }\end{array}$ \\
\hline & & Chir99 & $\begin{array}{l}\text { WN'l' } \\
\text { activation }\end{array}$ & $5 \mu \mathrm{M}$ & Induced accumulation of $\beta$-CATENIN & $\begin{array}{l}\text { Reduced development to the } \\
\text { blastocyst stage }\end{array}$ \\
\hline & & DKK1 & $\begin{array}{c}\text { WNT } \\
\text { inhibition }\end{array}$ & $100 \mathrm{ng} / \mathrm{mL}$ & $\begin{array}{l}\text { Decreased YAP1 in TE. Did not affect number of ICM or } \\
\text { TE cells }\end{array}$ & $\begin{array}{l}\text { No effects on embryonic } \\
\text { development }\end{array}$ \\
\hline & & WNI7A & $\begin{array}{l}\text { WN'l' } \\
\text { activation }\end{array}$ & $66 \mathrm{ng} / \mathrm{ml}$ & $\begin{array}{l}\text { Inlibited the PCP' pathway and did not affect amounts } \\
\text { of } \beta \text {-CATENIN }\end{array}$ & Increased blastocyst development \\
\hline \multicolumn{2}{|l|}{$\begin{array}{l}\text { Sidrat et al., } \\
2020\end{array}$} & 6-Bio & $\begin{array}{l}\text { WNT } \\
\text { activation }\end{array}$ & $400 \mathrm{nM}$ & 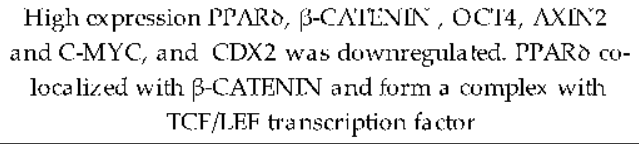 & $\begin{array}{l}\text { Enhanced blaslocyst formation, } \\
\text { quality and hatching rates }\end{array}$ \\
\hline \multicolumn{2}{|c|}{ Xia o et a1., 2021 day 4 to 7.5} & TWR1 & VNT inhibitio & $2.5 \mu \mathrm{M}$ & $\begin{array}{l}\text { Decrease lineage of STAT3 cells. Does not a ffect number } \\
\text { of cells }\end{array}$ & N.D. \\
\hline
\end{tabular}


Table 1 (cont): Different molecules and their effects on factors related to pluripotency and embryonic development in cattle.

\begin{tabular}{|c|c|c|c|c|c|c|}
\hline Reference & $\begin{array}{l}\text { Days in } \\
\text { culture }\end{array}$ & Molecule & Effect & Concentration & Effects on pluripotency-related factors & Effects on early development \\
\hline \multicolumn{7}{|c|}{ 2. MEK/ERK PATHWAY } \\
\hline $\begin{array}{l}\text { Kuijk et al., } \\
2012\end{array}$ & day 1-8 & $\begin{array}{l}\text { PD9 } 8079 \text { or } \\
\text { PD032 }\end{array}$ & $\begin{array}{l}\text { MEK } \\
\text { inhibition }\end{array}$ & $25 \mu \mathrm{M}$ & $\begin{array}{c}\text { More NANOG-positive cells than GATA6-positive cells. } \\
\text { lnduced specification of hypoblast markers }\end{array}$ & N.D. \\
\hline $\begin{array}{l}\text { Canizo et al., } \\
2019\end{array}$ & $\begin{array}{l}\text { day } 5 \\
\text { onward }\end{array}$ & $\mathrm{PD} 032$ & $\begin{array}{l}\text { MEK } \\
\text { inhibition }\end{array}$ & $0.4-2 \mu \mathrm{M}$ & $\begin{array}{c}\text { Increased the total number of cells by increasing TE cells } \\
\text { but reducing ICM cell number. Prevented hypoblast } \\
\text { segregation }\end{array}$ & $\begin{array}{l}\text { No effects on embryonic } \\
\text { development }\end{array}$ \\
\hline $\begin{array}{l}\text { Madeja et al., } \\
2019\end{array}$ & day $1-9$ & $2 i$ & $\begin{array}{l}\text { MEK } \\
\text { inhibition }\end{array}$ & $\begin{array}{r}\text { PD032 } 1 \mu \mathrm{M}+ \\
\text { Chir99 } 3 \mu \mathrm{M}\end{array}$ & $\begin{array}{l}\text { Higher apoptosis rate. No changes of BAX, BCL2, BAK, } \\
\text { BAX/BCL2 ratio. The expression of embryo } \\
\text { quality genes (HSPA1 A, SLC2A1) not affected. Reduced } \\
\text { expresion of IFNT2 }\end{array}$ & $\begin{array}{l}\text { No effects on embryonic } \\
\text { development }\end{array}$ \\
\hline $\begin{array}{l}\text { Springer et al., } \\
2021\end{array}$ & $\begin{array}{l}\text { day } 5 \\
\text { onward }\end{array}$ & $\mathrm{PD} 032$ & $\begin{array}{l}\text { MFK } \\
\text { inhibition }\end{array}$ & 0.5 or $2.5 \mu \mathrm{M}$ & $\begin{array}{l}\text { NANOG positive cells increased, while the expression of } \\
\text { GATA6 was reduced }\end{array}$ & $\begin{array}{c}\text { No effects on embryonic } \\
\text { development }\end{array}$ \\
\hline \multicolumn{7}{|l|}{$3.2 \mathrm{i}$} \\
\hline $\begin{array}{l}\text { Hatris et al., } \\
2013\end{array}$ & day 1-8 & $2 i$ & $\begin{array}{l}\text { MFKinhibiti } \\
\text { on/WNTacti } \\
\text { vation }\end{array}$ & 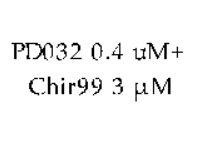 & $\begin{array}{c}\text { Increases expression of Nanog, SOX2 and cell numbers } \\
\text { in the trophoblast and TCM. Repressing putative } \\
\text { hypoblast marker GATA4. OCT4 and SOX2 were not } \\
\text { affected }\end{array}$ & $\begin{array}{l}\text { Improves development. Promoted } \\
\text { specifica toin of epiblast markers }\end{array}$ \\
\hline $\begin{array}{l}\text { McI.Fan et a1., } \\
2014\end{array}$ & $\begin{array}{l}\text { day } 5 \\
\text { onward }\end{array}$ & $2 i$ & $\begin{array}{l}\text { MEKinhibiti } \\
\text { on/WNTacti } \\
\text { vation }\end{array}$ & $\begin{array}{l}\text { PD0320.4 } \mu \mathrm{M}+ \\
\text { Chir99 } 3 \mu \mathrm{M}\end{array}$ & $\begin{array}{c}\text { Higher expression of NANOG and FGF4 and cell } \\
\text { number in ICM, while reducing PDKFRalpha and } \\
\text { SOXI7 levels }\end{array}$ & $\begin{array}{l}\text { No developmental changes. } \\
\text { Promoted sperificatoin of epiblast } \\
\text { markers }\end{array}$ \\
\hline \multirow{2}{*}{$\begin{array}{l}\text { Warrych et a1., } \\
2020\end{array}$} & \multirow{2}{*}{ day $1-9$} & $2 \mathrm{i}^{+}$ & $\begin{array}{l}\text { MEKinhibiti } \\
\text { on/WNTacti } \\
\text { vation }\end{array}$ & $\begin{array}{c}\text { PD032 } 10 \mu \mathrm{M}+ \\
\text { Chir99 } 3 \mu \mathrm{M}\end{array}$ & \multirow{2}{*}{$\begin{array}{l}\text { Upregulation of NANOG and OCT4 in the ICM and } \\
\text { downregulation of CDX2. Increase of OCT4 and } \\
\text { NANOG positive cells within the ICM and TE. Promoted } \\
\text { specifica to in of epiblast markers }\end{array}$} & $\begin{array}{l}\text { Improvement blastocyst } \\
\text { morphology, but no changes on } \\
\text { cell numbers }\end{array}$ \\
\hline & & $2 \mathrm{i}$ & $\begin{array}{l}\text { MLKinhibiti } \\
\text { on } / \text { WNTacti } \\
\text { vation }\end{array}$ & $\begin{array}{r}\text { P'D0321 } 1 \mu \mathrm{M}+ \\
\text { Chir99 } 3 \mu \mathrm{M}\end{array}$ & & N.D. \\
\hline
\end{tabular}

\begin{tabular}{|c|c|c|c|c|c|c|}
\hline $\begin{array}{l}\text { McLLan et al., } \\
2014\end{array}$ & $\begin{array}{l}\text { day } 5 \\
\text { onward }\end{array}$ & $3 \mathrm{i} / 3 \mathrm{i}+$ & $\begin{array}{l}\text { MEKinhibiti } \\
\text { on/WNTacti } \\
\text { vation/lali } \\
\text { Rinhibitor }\end{array}$ & $\begin{array}{l}\text { PD03210 } \mu \mathrm{M}+ \\
\text { Chir99 } 3 \mu \mathrm{M}++ \\
\text { PD170.1 } \mu \mathrm{M}\end{array}$ & $\begin{array}{l}\text { Increase in TE numbers only under additional FGFR } \\
\text { inhibition. Overexpression of NANOG and IGI } 4 \text { was } \\
\text { less consistent. }\end{array}$ & $\begin{array}{l}\text { Inprovement blastocyst } \\
\text { morphology }\end{array}$ \\
\hline $\begin{array}{l}\text { Madcja el al., } \\
2019\end{array}$ & & $3 i$ & $\begin{array}{l}\text { MEKinhibiti } \\
\text { on/WNlacti } \\
\text { vation/FGF } \\
\text { Rinhibitor }\end{array}$ & $\begin{array}{l}\text { PDI80.8 } \mu \mathrm{M}+ \\
\text { Chir99 } 3 \mu \mathrm{M}+ \\
\text { SU5402 } 2 \mu \mathrm{M}\end{array}$ & $\begin{array}{l}\text { Higher expression of } \mathrm{G}] \Lambda 1 \text { and cell-to-cell inleraclions } \\
\text { transcripts }\end{array}$ & $\begin{array}{l}\text { Promotes cell-to-cell interactions } \\
\text { butl lower cmbryonic quality }\end{array}$ \\
\hline $\begin{array}{l}\text { Warzych et al. } \\
2020\end{array}$ & & $3 i / 3 i+$ & $\begin{array}{l}\text { MEKinhibiti } \\
\text { on/WNTacti } \\
\text { vation/FCFF } \\
\text { Rinhibitor }\end{array}$ & $\begin{array}{c}\text { PD1840.8 } \mu \mathrm{M}+ \\
\text { Chirg9 } 3 \mu \mathrm{M}+2 \\
\mu \mathrm{M} \text { SU5402 }\end{array}$ & $\begin{array}{l}\text { Upregulation of NANOG and OCT4 in the ICM and } \\
\text { downregutation of CDX2. Increase of OCT4 and } \\
\text { NA.NOG positive celts within the ICM and TE. }\end{array}$ & N.D. \\
\hline $\begin{array}{l}\text { Han et al., } \\
2020\end{array}$ & day $2-8$ & $3 i$ & $\begin{array}{l}\text { MLKinhibili } \\
\text { on/WNTacti } \\
\text { vation/WD } \\
\text { R5inhibitio } \\
n\end{array}$ & $\begin{array}{l}\text { Chir99 } 0.5 \mu \mathrm{M}+ \\
\text { PD0320.5 } \mu \mathrm{M}+ \\
\text { MM102 } 30 \mu \mathrm{M}\end{array}$ & $\begin{array}{l}\text { Reduced cxpression of ICM-related gene (OCT4, SOX2 } \\
\text { and NANOG). Increases the expression of KLF4 and } \\
\text { KI.F17 and decreases the expression of the de novo DNA } \\
\text { methyltransferase genes DNMT3L a nd DNMT1 }\end{array}$ & Improved blastocyst development \\
\hline
\end{tabular}


Table 1 (cont): Different molecules and their effects on factors related to pluripotency and embryonic development in cattle.

\begin{tabular}{|c|c|c|c|c|c|c|}
\hline Reference & $\begin{array}{l}\text { Days in } \\
\text { culture }\end{array}$ & Molecule & Effect & Concentration & Effects on pluripotency-related factors & Effects on early development \\
\hline \multicolumn{7}{|l|}{ 5. JAK/STAT } \\
\hline $\begin{array}{l}\text { Vejlsted et al., } \\
2005\end{array}$ & $\begin{array}{l}\text { day } 5 \\
\text { onward }\end{array}$ & LIF & $\begin{array}{l}\text { JAK/STAT } \\
\text { activation }\end{array}$ & $1000 \mathrm{~L} / \mathrm{mL}$ & Reduced cell count and expression of OCT4 & $\begin{array}{l}\text { Adverse effects on development } \\
\text { based on kinetics and morphology }\end{array}$ \\
\hline $\begin{array}{l}\text { Rodriguez et } \\
\text { al., } 2007\end{array}$ & $\begin{array}{l}\text { day } 6 \\
\text { onward }\end{array}$ & LIF & $\begin{array}{l}\text { JAK/STAT } \\
\text { activation }\end{array}$ & $100 \mathrm{ng} / \mathrm{mL}$ & $\begin{array}{l}\text { Decreased cell counts both in terms of inner cell mass } \\
\text { (ICM) and ICM/total cell proportions }\end{array}$ & N.D. \\
\hline $\begin{array}{l}\text { Kuijk et al. } \\
2012\end{array}$ & day $1-8$ & FGF4 & $\begin{array}{l}\text { FGF } \\
\text { activation }\end{array}$ & $\mathrm{I} \mu \mathrm{g} / \mathrm{mL}$ & $\begin{array}{c}\text { Reduced numbers of.NANOG-positive cells and } \\
\text { enhanced numbers of GATA6-positive cells. No effects on } \\
\text { CDX2. From the morula stage onwards ICMs were } \\
\text { composed entirely of CATA6-cells. Induced specification } \\
\text { of hypoblast markers }\end{array}$ & N.D. \\
\hline $\begin{array}{l}\text { Meng et al., } \\
2015\end{array}$ & $\begin{array}{l}\text { day } 5 \\
\text { onward }\end{array}$ & $\mathrm{A} \angle \mathrm{D} 1480$ & $\begin{array}{l}\text { JAK/STAT } \\
\text { activation }\end{array}$ & $10 \mu \mathrm{M}$ & $\begin{array}{l}\text { Affect ICM formation but trophectoderm cell numbers } \\
\text { and markers (CDX2) nol altered. JAK inhibition } \\
\text { repressed both cpiblast and hypoblast factors }\end{array}$ & N.D. \\
\hline $\begin{array}{l}\text { Kocyigit et al., } \\
2017\end{array}$ & $\begin{array}{l}\text { day } 4 \\
\text { onward }\end{array}$ & LIF & $\begin{array}{l}\text { JAK/STAT } \\
\text { activation }\end{array}$ & $100 \mathrm{ng} / \mathrm{mL}$ & Induces specification of hypoblast markers & $\begin{array}{l}\text { Promoted blastocyst development } \\
\text { only when added on day } 4 \text {. } \\
\text { Detrimental effects on } \\
\text { development when added at day } \\
0 \text { and/or from day } 4 \text { to } 7\end{array}$ \\
\hline $\begin{array}{l}\text { Canizo et al. } \\
2019\end{array}$ & $\begin{array}{l}\text { day } 5 \\
\text { onward }\end{array}$ & LIF & $\begin{array}{l}\text { JAK/STAT } \\
\text { activation }\end{array}$ & $20 \mathrm{ng} / \mathrm{mL}$ & $\begin{array}{c}\text { Trophic effect in the bovine TCM by increasing } \mathrm{NANOC} \\
\text { and SOX } 17 \text { positive cells at day } 8 \text {. }\end{array}$ & $\begin{array}{l}\text { Boost the blastocyst yields an a } \\
\text { trophic effect on the hypoblast. }\end{array}$ \\
\hline
\end{tabular}

*ICM: inner cell mass; TE: trophectoderm; Chir99: Chir99021; PD17: PD173074; PD18: PD184325

\section{The role of pluripotency on biotechnological applications}

\subsection{In vitro embryo production}

IVP technology have become commercially viable and extensively used for producing embryos in cattle [73]. It is also known that in vitro culture conditions determine embryo quality, expressed as developmental kinetic, blastomere count, efficiency of EGA, gene expression, apoptotic rates, etc [74]. Thus, modifications of the culture system, particularly before the time of EGA can significantly impact the pluripotency profile and quality of the resulting blastocysts. For example, activation or inhibition of the WNT and silencing of the MEK/ ERK signalling alter critical pathways associated with apoptosis, implantation, and maternal recognition of pregnancy $[39,66]$. However, only few studies have evaluated if control of pluripotency at pre-implantation stages can influence postimplantation, deliver and/or in vivo development in bovine species. For instance, the study of Tribulo et al., [75] found that calves derived from embryos exposed to DKK1 from morula to blastocyst stage had lower birth weight compared to the control group, suggesting that changes in molecular signaling during early developmental stages impact postnatal phenotype. Recently, Han et al [29] evaluated the developmental effects of a modified $3 i$ system on bovine and mouse IVF efficiency, and they transferred mouse 3i-embryos to surrogate females. They did not find any differences on birth rate, sex ratio, morphology, 
or body weight compared with the progeny of the control group. Besides, the 3i-offspring produced normal pups, indicating that fertility of mice developed from the inhibited embryos was not affected. In this sense, it would be important to continue studying physiological changes induced by chemical inhibitors to get more insights on later impacts on pre- and post-implantation development.

Besides, it is well-known that most of embryos generated by IVF technologies (IVF, SCNT, or ICSI) do not gather the required morphological quality to be transferred [45]. Therefore, the chemical control of cell differentiation pathways and pluripotent profiles raises as a valid strategy to "rescue" the developmental potential from embryos of lower quality to obtain embryos in vitro efficiently, especially in large animals (Figure 3).

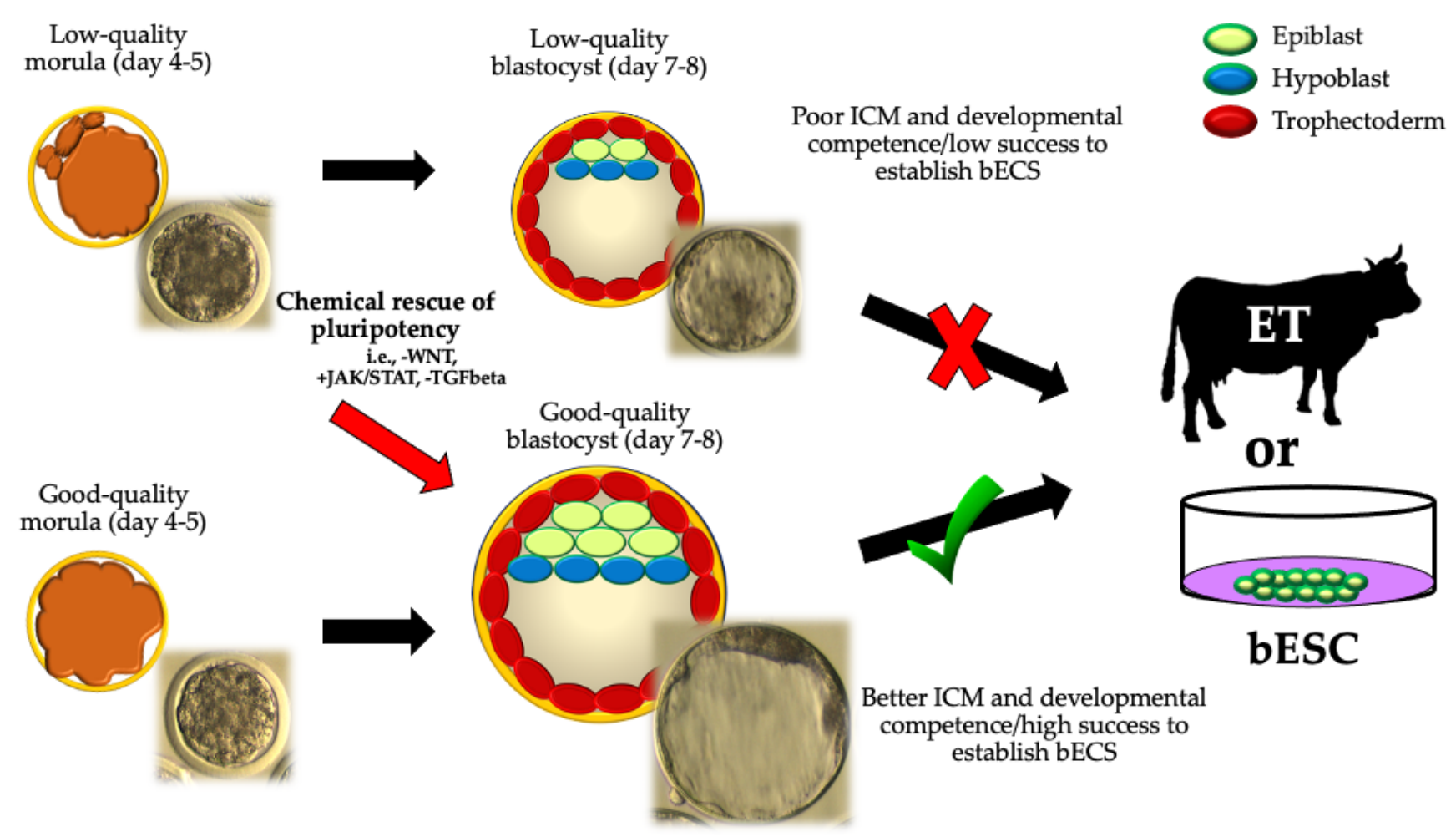

Figure 3. A theoretical approach to "rescue" in vitro developmental potential from cattle embryos of lower quality (seen as morula with delayed compaction, presence of cell debris, fragmentation and/or slower developmental kinetics). ICM: inner cell mass; ET: embryo transfer; bESCs: bovine embryonic stem cells. Low quality blastocyst: embryos with delayed blastulation, poor symmetry, and/or cells that are loosely packed for the ICM and trophectoderm). Instead, good-quality blastocyst: embryos with an expanded blastocoel cavity, highly symmetric, absence of cell debris or fragmentation, and highly packed ICM and trophectoderm cells, where a clearly visible ICM can be distinguished during morphological valuation).

In addition, another approach used to optimize in vitro embryo production efficiency in cattle species has been supplementing culture media with biologically active molecules produced by the reproductive tract or embryo in early pregnancy. Hansen and colleagues called "embryokine", such as CSF2, to molecules produced by the female reproductive and embryo tract that control embryonic development and pluripotency [76]. Topics have been reviewed in detail elsewhere [76,77]. Thus, the control of molecular interactions of signaling pathways critical for cellular differentiation and pluripotency leads to strategies seeking to optimize IVP conditions and boost embryonic developmental potential. 


\subsection{Capturing pluripotency in vitro}

Nowadays because to the improved understanding of pluripotency, stemness from cattle species can be captured in vitro [78] by deriving embryonic stem cells from biparental embryos produced by IVF. Pluripotent stem cells can also be derived from somatic cells, the induced pluripotent stem cells (iPSCs) [79,80].

Bogliotti et al. [35] employed fibroblast growth factor 2 (FGF2) and a canonical WNT signaling pathway inhibitor in their culture conditions, and derived stable pluripotent cell lines from bovine blastocysts. Bovine pluripotent cells express pluripotent markers SOX2 and POU5F1, and are negative for CDX2 and the hypoblast marker GATA6 [78,81,82]. Thus, inhibition of Wnt signaling by IWR-1 and stimulation of FGF2 pathway seems to be essential requirements to derive bovine ESCs lines [82]. Xiao et al [39] evaluated the effects of different WNT inhibitors on derivation efficiency of bovine ESCs. They found that canonical WNT signaling is antagonistic to pluripotency and that derivation of pluripotent ESCs involves inhibition of WNT signaling. Nonetheless, not all inhibitors showed the same efficacy, with IWR-1 and IWP2 being effective while XAV939 and DKK1 not.

On the other hand, bovine iPSCs have been generated from somatic cells using exogenous transcriptional factors combined with the use of small chemical inhibitors supported by current knowledge of pluripotential pathways. Su et al using a combination of seven factors (OCT4, SOX2, NANOG, KLF4, cMYC, LIN28 and KDM4A), and the reprogramming medium containing inhibitors to WNT (IWR1) and H3K79 methyltransferase Dot1L (iDot1L) derived primed-like iPSCs from mesenchymal stem cells, where OCT4, NANOG, and SOX2 were highly activated in these iPSCs across different passages [80]. Similarly, Pillai et al [79] enhanced the celllular reprogramming of bovine fibroblasts to biPSCs by forcing expression of OCT4, SOX2, KLF4 and MYC, but also reported that inhibition of ALK4/5/7 to block TGF $\beta /$ activin/nodal signaling together with GSK3 $\beta$ and MEK1/2, supported robust in vitro self-renewal of naïve biPSCs.

\section{Conclusions}

In the present manuscript, we reviewed the current knowledge of core pluripotency markers during early development of bovine embryos. We also described the main pathways involved in pluripotency maintenance and cell-differentiation. Embryonic pluripotency depends on activation of several molecular mechanism involving different factors where the rigorous balance between maternal clearance and zygotic expression of OCT4, NANOG, SOX2 and CDX2 impact differentiation, proliferation, apoptosis, and embryonic quality. In addition, the WNT signaling seems to play a crucial role in driving both, cell differentiation and pluripotency maintenance in bovine species. The recent derivation of PSCs (ESCs and iPSCs) is a hallmark of progresses concerning pluripotency in cattle species. Besides, there is a great potential to optimize in vitro culture conditions by controlling cell differentiation networks, such as incorporating small molecules and avoiding the need for undefined culture components. In this line, manipulating pluripotency networks of low quality-embryos produced by IVF technologies can certainly rescue their developmental competence and increase the efficiency of IVP, especially in large species. However, chemical modulation will depend on time of exposure, concentrations, and secondary targeting of the small molecule(s). Even, the base medium used (i.e., SOF, KSOM, $\mathrm{N} 2 \mathrm{~B} 27$, etc), can undoubtedly influence the final outcomes. Indeed, the generation of more specific antibodies, genetic engineering, and advanced technologies such as deep sequencing approaches have contributed significantly to understand how early development in mammals diverges in their pluripotent characteristics and to establish favorable conditions to capture cattle pluripotency in vitro.

Author Contributions: “Conceptualization, LA, CO-S, FT; writing LA, CO-S, FT, RF - original draft preparation, LA, CO-S, FT; writing-review and editing LA, CO-S, FT, RF. All authors have read and agreed to the published version of the manuscript. 
Funding: This research was funded by Universidad de La Frontera, Programa de Formacion de Investigadores Postdoctorales (L.A).

Institutional Review Board Statement: Not applicable.

Informed Consent Statement: Not applicable.

Data Availability Statement: Not applicable.

Acknowledgments:

Conflicts of Interest: The authors declare no conflict of interest.

\section{References}

1. Rebuzzini, P.; Zuccotti, M.; Garagna, S. Building Pluripotency Identity in the Early Embryo and Derived Stem Cells. Cells 2021, 10, doi:10.3390/CELLS10082049.

2. Gilbert, S.F. Developmental biology. 2003, 838.

3. Chazaud, C.; Yamanaka, Y.; Pawson, T.; Rossant, J. Early lineage segregation between epiblast and primitive endoderm in mouse blastocysts through the Grb2-MAPK pathway. Dev. Cell 2006, 10, 615-624, doi:10.1016/J.DEVCEL.2006.02.020.

4. $\quad$ Ozawa, M.; Sakatani, M.; Yao, J.; Shanker, S.; Yu, F.; Yamashita, R.; Wakabayashi, S.; Nakai, K.; Dobbs, K.B.; Sudano, M.J.; et al. Global gene expression of the inner cell mass and trophectoderm of the bovine blastocyst. BMC Dev. Biol. 2012, 12, doi:10.1186/1471-213X-12-33.

5. Warzych, E.; Pawlak, P.; Lechniak, D.; Madeja, Z.E. WNT signalling supported by MEK/ERK inhibition is essential to maintain pluripotency in bovine preimplantation embryo. Dev. Biol. 2020, 463, 63-76, doi:10.1016/J.YDBIO.2020.04.004.

6. Piliszek, A.; Madeja, Z.E. Pre-implantation Development of Domestic Animals. Curr. Top. Dev. Biol. 2018, 128, 267-294, doi:10.1016/BS.CTDB.2017.11.005.

7. Khan, D.R.; Dubé, D.; Gall, L.; Peynot, N.; Ruffini, S.; Laffont, L.; Le Bourhis, D.; Degrelle, S.; Jouneau, A.; Duranthon, V. Expression of pluripotency master regulators during two key developmental transitions: EGA and early lineage specification in the bovine embryo. PLoS One 2012, 7, doi:10.1371/JOURNAL.PONE.0034110.

8. Sakurai, N.; Takahashi, K.; Emura, N.; Fujii, T.; Hirayama, H.; Kageyama, S.; Hashizume, T.; Sawai, K. The Necessity of OCT-4 and CDX2 for Early Development and Gene Expression Involved in Differentiation of Inner Cell Mass and Trophectoderm Lineages in Bovine Embryos. Cell. Reprogram. 2016, 18, 309-318, doi:10.1089/CELL.2015.0081.

9. Madeja, Z.E.; Hryniewicz, K.; Orsztynowicz, M.; Pawlak, P.; Perkowska, A. WNT/ $\beta$-catenin signaling affects cell lineage and pluripotency-specific gene expression in bovine blastocysts: prospects for bovine embryonic stem cell derivation. Stem Cells Dev. 2015, 24, 2437-2454, doi:10.1089/SCD.2015.0053.

10. Daigneault, B.W.; Rajput, S.; Smith, G.W.; Ross, P.J. Embryonic POU5F1 is Required for Expanded Bovine Blastocyst Formation. Sci. Rep. 2018, 8, doi:10.1038/S41598-018-25964-X.

11. Simmet, K.; Zakhartchenko, V.; Philippou-Massier, J.; Blum, H.; Klymiuk, N.; Wolf, E. OCT4/POU5F1 is required for NANOG expression in bovine blastocysts. Proc. Natl. Acad. Sci. U. S. A. 2018, 115, 2770-2775, doi:10.1073/PNAS.1718833115.

12. Degrelle, S.A.; Campion, E.; Cabau, C.; Piumi, F.; Reinaud, P.; Richard, C.; Renard, J.P.; Hue, I. Molecular 
evidence for a critical period in mural trophoblast development in bovine blastocysts. Dev. Biol. 2005, 288, 448460, doi:10.1016/J.YDBIO.2005.09.043.

13. Kurosaka, S.; Eckardt, S.; McLaughlin, K.J. Pluripotent lineage definition in bovine embryos by Oct4 transcript localization. Biol. Reprod. 2004, 71, 1578-1582, doi:10.1095/BIOLREPROD.104.029322.

14. Kirchhof, N.; Carnwath, J.W.; Lemme, E.; Anastassiadis, K.; Scholer, H.; Niemann, H. Expression pattern of Oct4 in preimplantation embryos of different species. Biol. Reprod. 2000, 63, 1698-1705, doi:10.1095/BIOLREPROD63.6.1698.

15. Van Eijk, M.J.T.; Van Rooijen, M.A.; Modina, S.; Scesi, L.; Folkers, G.; Van Tol, H.T.A.; Bevers, M.M.; Fisher, S.R.; Lewin, H.A.; Rakacolli, D.; et al. Molecular cloning, genetic mapping, and developmental expression of bovine POU5F1. Biol. Reprod. 1999, 60, 1093-1103, doi:10.1095/BIOLREPROD60.5.1093.

16. Shi, Y.; Zhao, P.; Dang, Y.; Li, S.; Luo, L.; Hu, B.; Wang, S.; Wang, H.; Zhang, K. Functional roles of the chromatin remodeler SMARCA5 in mouse and bovine preimplantation embryost. Biol. Reprod. 2021, 105, 359-370, doi:10.1093/BIOLRE/IOAB081.

17. Brinkhof, B.; van Tol, H.T.A.; Groot Koerkamp, M.J.A.; Riemers, F.M.; Ijzer, S.G.; Mashayekhi, K.; Haagsman, H.P.; Roelen, B.A.J. A mRNA landscape of bovine embryos after standard and MAPK-inhibited culture conditions: a comparative analysis. BMC Genomics 2015, 16, doi:10.1186/S12864-015-1448-X.

18. Vigneault, C.; McGraw, S.; Massicotte, L.; Sirard, M.A. Transcription factor expression patterns in bovine in vitro-derived embryos prior to maternal-zygotic transition. Biol. Reprod. 2004, 70, 1701-1709, doi:10.1095/BIOLREPROD.103.022970.

19. Madeja, Z.E.; Sosnowski, J.; Hryniewicz, K.; Warzych, E.; Pawlak, P.; Rozwadowska, N.; Plusa, B.; Lechniak, D. Changes in sub-cellular localisation of trophoblast and inner cell mass specific transcription factors during bovine preimplantation development. BMC Dev. Biol. 2013, 13, doi:10.1186/1471-213X-13-32.

20. Berg, D.K.; Smith, C.S.; Pearton, D.J.; Wells, D.N.; Broadhurst, R.; Donnison, M.; Pfeffer, P.L. Trophectoderm lineage determination in cattle. Dev. Cell 2011, 20, 244-255, doi:10.1016/J.DEVCEL.2011.01.003.

21. Akizawa, H.; Saito, S.; Kohri, N.; Furukawa, E.; Hayashi, Y.; Bai, H.; Nagano, M.; Yanagawa, Y.; Tsukahara, H.; Takahashi, M.; et al. Deciphering two rounds of cell lineage segregations during bovine preimplantation development. FASEB J. 2021, 35, doi:10.1096/FJ.202002762RR.

22. Kashyap, V.; Rezende, N.C.; Scotland, K.B.; Shaffer, S.M.; Persson, J.L.; Gudas, L.J.; Mongan, N.P. Regulation of stem cell pluripotency and differentiation involves a mutual regulatory circuit of the NANOG, OCT4, and SOX2 pluripotency transcription factors with polycomb repressive complexes and stem cell microRNAs. Stem Cells Dev. 2009, 18, 1093-1108, doi:10.1089/SCD.2009.0113.

23. Ezashi, T.; Ghosh, D.; Roberts, R.M. Repression of Ets-2-induced transactivation of the tau interferon promoter by Oct-4. Mol. Cell. Biol. 2001, 21, 7883-7891, doi:10.1128/MCB.21.23.7883-7891.2001.

24. Nganvongpanit, K.; Müller, H.; Rings, F.; Hoelker, M.; Jennen, D.; Tholen, E.; Havlicek, V.; Besenfelder, U.; Schellander, K.; Tesfaye, D. Selective degradation of maternal and embryonic transcripts in in vitro produced bovine oocytes and embryos using sequence specific double-stranded RNA. Reproduction 2006, 131, 861-874, doi:10.1530/REP.1.01040.

25. Long, J.E.; Cai, X.; He, L.Q. Gene profiling of cattle blastocysts derived from nuclear transfer, in vitro fertilization and in vivo development based on cDNA library. Anim. Reprod. Sci. 2007, 100, 243-256, doi:10.1016/J.ANIREPROSCI.2006.07.006.

26. Gómez, E.; Caamaño, J.N.; Bermejo-Alvarez, P.; Díez, C.; Muñoz, M.; Martín, D.; Carrocera, S.; Gutiérrez-Adán, A. Gene expression in early expanded parthenogenetic and in vitro fertilized bovine blastocysts. J. Reprod. Dev. 


\section{9, 55, 607-614, doi:10.1262/JRD.09-077M.}

27. Mitsui, K.; Tokuzawa, Y.; Itoh, H.; Segawa, K.; Murakami, M.; Takahashi, K.; Maruyama, M.; Maeda, M.; Yamanaka, S. The homeoprotein Nanog is required for maintenance of pluripotency in mouse epiblast and ES cells. Cell 2003, 113, 631-642, doi:10.1016/S0092-8674(03)00393-3.

28. Kuijk, E.W.; van Tol, L.T.A.; van de Velde, H.; Wubbolts, R.; Welling, M.; Geijsen, N.; Roelen, B.A.J. The roles of FGF and MAP kinase signaling in the segregation of the epiblast and hypoblast cell lineages in bovine and human embryos. Development 2012, 139, 871-882, doi:10.1242/DEV.071688.

29. Han, X.; Xiang, J.; Li, C.; Wang, J.; Wang, C.; Zhang, Y.; Li, Z.; Lu, Z.; Yue, Y.; Li, X. MLL1 combined with GSK3 and MAP2K inhibition improves the development of in vitro-fertilized embryos. Theriogenology 2020, 146, 58-70, doi:10.1016/J.THERIOGENOLOGY.2020.01.051.

30. Cao, S.; Wang, F.; Chen, Z.; Liu, Z.; Mei, C.; Wu, H.; Huang, J.; Li, C.; Zhou, L.; Lin, L. Isolation and culture of primary bovine embryonic stem cell colonies by a novel method. J. Exp. Zool. A. Ecol. Genet. Physiol. 2009, 311, 368-376, doi:10.1002/JEZ.535.

31. Meng, F.; Forrester-Gauntlett, B.; Turner, P.; Henderson, H.; Oback, B. Signal Inhibition Reveals JAK/STAT3 Pathway as Critical for Bovine Inner Cell Mass Development. Biol. Reprod. 2015, 93, doi:10.1095/BIOLREPROD.115.134254.

32. Zhao, X.M.; Cui, L.S.; Hao, H.S.; Wang, H.Y.; Zhao, S.J.; Du, W.H.; Wang, D.; Liu, Y.; Zhu, H.B. Transcriptome analyses of inner cell mass and trophectoderm cells isolated by magnetic-activated cell sorting from bovine blastocysts using single cell RNA-seq. Reprod. Domest. Anim. 2016, 51, 726-735, doi:10.1111/RDA.12737.

33. Springer, C.; Zakhartchenko, V.; Wolf, E.; Simmet, K. Hypoblast Formation in Bovine Embryos Does Not Depend on NANOG. Cells 2021, 10, doi:10.3390/CELLS10092232.

34. Ortega, M.S.; Kelleher, A.M.; O'Neil, E.; Benne, J.; Cecil, R.; Spencer, T.E. NANOG is required to form the epiblast and maintain pluripotency in the bovine embryo. Mol. Reprod. Dev. 2020, 87, 152-160, doi:10.1002/MRD.23304.

35. Bogliotti, Y.S.; Wu, J.; Vilarino, M.; Okamura, D.; Soto, D.A.; Zhong, C.; Sakurai, M.; Sampaio, R.V.; Suzuki, K.; Izpisua Belmonte, J.C.; et al. Efficient derivation of stable primed pluripotent embryonic stem cells from bovine blastocysts. Proc. Natl. Acad. Sci. U. S. A. 2018, 115, 2090-2095, doi:10.1073/PNAS.1716161115.

36. Canizo, J.R.; Ynsaurralde Rivolta, A.E.; Vazquez Echegaray, C.; Suvá, M.; Alberio, V.; Aller, J.F.; Guberman, A.S.; Salamone, D.F.; Alberio, R.H.; Alberio, R. A dose-dependent response to MEK inhibition determines hypoblast fate in bovine embryos. BMC Dev. Biol. 2019, 19, doi:10.1186/S12861-019-0193-9.

37. Kuijk, E.W.; Du Puy, L.; Van Tol, H.T.A.; Oei, C.H.Y.; Haagsman, H.P.; Colenbrander, B.; Roelen, B.A.J. Differences in early lineage segregation between mammals. Dev. Dyn. 2008, 237, 918-927, doi:10.1002/DVDY.21480.

38. Gerri, C.; McCarthy, A.; Alanis-Lobato, G.; Demtschenko, A.; Bruneau, A.; Loubersac, S.; Fogarty, N.M.E.; Hampshire, D.; Elder, K.; Snell, P.; et al. Initiation of a conserved trophectoderm program in human, cow and mouse embryos. Nature 2020, 587, 443-447, doi:10.1038/S41586-020-2759-X.

39. Xiao, Y.; Amaral, T.F.; Ross, P.J.; Soto, D.A.; Diffenderfer, K.E.; Pankonin, A.R.; Jeensuk, S.; Tríbulo, P.; Hansen, P.J. Importance of WNT-dependent signaling for derivation and maintenance of primed pluripotent bovine embryonic stem cellst. Biol. Reprod. 2021, 105, 52-63, doi:10.1093/BIOLRE/IOAB075.

40. Denicol, A.C.; Dobbs, K.B.; McLean, K.M.; Carambula, S.F.; Loureiro, B.; Hansen, P.J. Canonical WNT signaling regulates development of bovine embryos to the blastocyst stage. Sci. Rep. 2013, 3, doi:10.1038/SREP01266.

41. Tribulo, P.; da Silva Leão, B.C.; Lehloenya, K.C.; Mingoti, G.Z.; Hansen, P.J. Consequences of endogenous and exogenous WNT signaling for development of the preimplantation bovine embryo. Biol. Reprod. 2017, 96, 1129- 


\section{1, doi:10.1093/BIOLRE/IOX048.}

42. Goissis, M.D.; Cibelli, J.B. Functional characterization of CDX2 during bovine preimplantation development in vitro. Mol. Reprod. Dev. 2014, 81, 962-970, doi:10.1002/MRD.22415.

43. Mistri, T.K.; Arindrarto, W.; Ng, W.P.; Wang, C.; Lim, L.H.; Sun, L.; Chambers, I.; Wohland, T.; Robson, P. Dynamic changes in Sox2 spatio-temporal expression promote the second cell fate decision through Fgf4/ Fgfr2 signaling in preimplantation mouse embryos. Biochem. J. 2018, 475, 1075-1089, doi:10.1042/BCJ20170418.

44. Velásquez, A.E.; Veraguas, D.; Cabezas, J.; Manríquez, J.; Castro, F.O.; Rodríguez-Alvarez, L.L. The expression level of SOX2 at the blastocyst stage regulates the developmental capacity of bovine embryos up to day-13 of in vitro culture. Zygote 2019, 27, 398-404, doi:10.1017/S0967199419000509.

45. Hall, V.J.; Ruddock, N.T.; French, A.J. Expression profiling of genes crucial for placental and preimplantation development in bovine in vivo, in vitro, and nuclear transfer blastocysts. Mol. Reprod. Dev. 2005, 72, 16-24, doi:10.1002/MRD.20337.

46. Rodríguez-Alvarez, L.; Manriquez, J.; Velasquez, A.; Castro, F.O. Constitutive expression of the embryonic stem cell marker OCT4 in bovine somatic donor cells influences blastocysts rate and quality after nucleus transfer. In Vitro Cell. Dev. Biol. Anim. 2013, 49, 657-667, doi:10.1007/S11626-013-9650-0.

47. Rodŕguez-Alvarez, L.; Cox, J.; Tovar, H.; Einspanier, R.; Castro, F.O. Changes in the expression of pluripotencyassociated genes during preimplantation and peri-implantation stages in bovine cloned and in vitro produced embryos. Zygote 2010, 18, 269-279, doi:10.1017/S0967199409990323.

48. Wu, X.; Song, M.; Yang, X.; Liu, X.; Liu, K.; Jiao, C.; Wang, J.; Bai, C.; Su, G.; Liu, X.; et al. Establishment of bovine embryonic stem cells after knockdown of CDX2. Sci. Rep. 2016, 6, doi:10.1038/SREP28343.

49. Schiffmacher, A.T.; Keefer, C.L. CDX2 regulates multiple trophoblast genes in bovine trophectoderm CT-1 cells. Mol. Reprod. Dev. 2013, 80, 826-839, doi:10.1002/MRD.22212.

50. Nishioka, N.; Inoue, K. ichi; Adachi, K.; Kiyonari, H.; Ota, M.; Ralston, A.; Yabuta, N.; Hirahara, S.; Stephenson, R.O.; Ogonuki, N.; et al. The Hippo signaling pathway components Lats and Yap pattern Tead4 activity to distinguish mouse trophectoderm from inner cell mass. Dev. Cell 2009, 16, 398-410, doi:10.1016/J.DEVCEL.2009.02.003.

51. Yagi, R.; Kohn, M.J.; Karavanova, I.; Kaneko, K.J.; Vullhorst, D.; DePamphilis, M.L.; Buonanno, A. Transcription factor TEAD4 specifies the trophectoderm lineage at the beginning of mammalian development. Development 2007, 134, 3827-3836, doi:10.1242/DEV.010223.

52. Kohri, N.; Akizawa, H.; Iisaka, S.; Bai, H.; Yanagawa, Y.; Takahashi, M.; Komatsu, M.; Kawai, M.; Nagano, M.; Kawahara, M. Trophectoderm regeneration to support full-term development in the inner cell mass isolated from bovine blastocyst. J. Biol. Chem. 2019, 294, 19209-19223, doi:10.1074/JBC.RA119.010746.

53. Komiya, Y.; Habas, R. Wnt signal transduction pathways. Organogenesis 2008, 4, 68-75, doi:10.4161/ORG.4.2.5851.

54. Aparicio, I.M.; Garcia-Herreros, M.; Fair, T.; Lonergan, P. Identification and regulation of glycogen synthase kinase-3 during bovine embryo development. Reproduction 2010, 140, 83-92, doi:10.1530/REP-10-0040.

55. Werner, M.; del Castillo, U.; Ventrella, R.; Brotslaw, E.; Mitchell, B. The small molecule AMBMP disrupts microtubule growth, ciliogenesis, cell polarity, and cell migration. Cytoskeleton (Hoboken). 2018, 75, 450-457, doi:10.1002/CM.21496.

56. Harris, D.; Huang, B.; Oback, B. Inhibition of MAP2K and GSK3 signaling promotes bovine blastocyst development and epiblast-associated expression of pluripotency factors. Biol. Reprod. 2013, 88, doi:10.1095/BIOLREPROD.112.103390. 
57. Sidrat, T.; Khan, A.A.; Idrees, M.; Joo, M.D.; Xu, L.; Lee, K.L.; Kong, I.K. Role of Wnt Signaling During In-Vitro Bovine Blastocyst Development and Maturation in Synergism with PPARठ Signaling. Cells 2020, 9, doi:10.3390/CELLS9040923.

58. Denicol, A.C.; Block, J.; Kelley, D.E.; Pohler, K.G.; Dobbs, K.B.; Mortensen, C.J.; Ortega, M.S.; Hansen, P.J. The WNT signaling antagonist Dickkopf-1 directs lineage commitment and promotes survival of the preimplantation embryo. FASEB J. 2014, 28, 3975-3986, doi:10.1096/FJ.14-253112.

59. Tai, C.I.; Schulze, E.N.; Ying, Q.L. Stat3 signaling regulates embryonic stem cell fate in a dose-dependent manner. Biol. Open 2014, 3, 958-965, doi:10.1242/BIO.20149514.

60. Wang, C.; Han, X.; Zhou, Z.; Uyunbilig, B.; Huang, X.; Li, R.; Li, X. Wnt3a Activates the WNT-YAP/TAZ Pathway to Sustain CDX2 Expression in Bovine Trophoblast Stem Cells. DNA Cell Biol. 2019, 38, 410-422, doi:10.1089/DNA.2018.4458.

61. McLean, Z.; Meng, F.; Henderson, H.; Turner, P.; Oback, B. Increased MAP kinase inhibition enhances epiblastspecific gene expression in bovine blastocysts. Biol. Reprod. 2014, 91, doi:10.1095/BIOLREPROD.114.120832.

62. Verma, V.; Huang, B.; Kallingappa, P.K.; Oback, B. Dual kinase inhibition promotes pluripotency in finite bovine embryonic cell lines. Stem Cells Dev. 2013, 22, 1728-1742, doi:10.1089/SCD.2012.0481.

63. Shimada, A.; Nakano, H.; Takahashi, T.; Imai, K.; Hashizume, K. Isolation and characterization of a bovine blastocyst-derived trophoblastic cell line, BT-1: development of a culture system in the absence of feeder cell. Placenta 2001, 22, 652-662, doi:10.1053/PLAC.2001.0702.

64. Talbot, N.C.; Caperna, T.J.; Edwards, J.L.; Garrett, W.; Wells, K.D.; Ealy, A.D. Bovine blastocyst-derived trophectoderm and endoderm cell cultures: interferon tau and transferrin expression as respective in vitro markers. Biol. Reprod. 2000, 62, 235-247, doi:10.1095/BIOLREPROD62.2.235.

65. Yang, Q.E.; Fields, S.D.; Zhang, K.; Ozawa, M.; Johnson, S.E.; Ealy, A.D. Fibroblast growth factor 2 promotes primitive endoderm development in bovine blastocyst outgrowths. Biol. Reprod. 2011, 85, 946-953, doi:10.1095/BIOLREPROD.111.093203.

66. Madeja, Z.E.; Warzych, E.; Pawlak, P.; Lechniak, D. Inhibitor mediated WNT and MEK/ERK signalling affects apoptosis and the expression of quality related genes in bovine in vitro obtained blastocysts. Biochem. Biophys. Res. Commun. 2019, 510, 403-408, doi:10.1016/J.BBRC.2019.01.113.

67. Huang, X.; Han, X.; Uyunbilig, B.; Zhang, M.; Duo, S.; Zuo, Y.; Zhao, Y.; Yun, T.; Tai, D.; Wang, C.; et al. Establishment of bovine trophoblast stem-like cells from in vitro-produced blastocyst-stage embryos using two inhibitors. Stem Cells Dev. 2014, 23, 1501-1514, doi:10.1089/SCD.2013.0329.

68. Madsen, R.R. PI3K in stemness regulation: from development to cancer. Biochem. Soc. Trans. 2020, 48, 301-315, doi:10.1042/BST20190778.

69. Sirisathien, S.; Hernandez-Fonseca, H.J.; Bosch, P.; Hollet, B.R.; Lott, J.D.; Brackett, B.G. Effect of leukemia inhibitory factor on bovine embryos produced in vitro under chemically defined conditions. Theriogenology 2003, 59, 1751-1763, doi:10.1016/S0093-691X(02)01258-X.

70. Vejlsted, M.; Avery, B.; Gjorret, J.O.; Maddox-Hyttel, P. Effect of leukemia inhibitory factor (LIF) on in vitro produced bovine embryos and their outgrowth colonies. Mol. Reprod. Dev. 2005, 70, 445-454, doi:10.1002/MRD.20221.

71. Rodríguez, A.; De Frutos, C.; Díez, C.; Caamaño, J.N.; Facal, N.; Duque, P.; García-Ochoa, C.; Gómez, E. Effects of human versus mouse leukemia inhibitory factor on the in vitro development of bovine embryos. Theriogenology 2007, 67, 1092-1095, doi:10.1016/J.THERIOGENOLOGY.2006.11.015.

72. Kocyigit, A.; Cevik, M. Leucemia inhibitory factor; investigating the time-dependent effect on viability of 
vitrified bovine embryos. Reprod. Domest. Anim. 2017, 52, 1113-1119, doi:10.1111/RDA.13040.

73. Van Wagtendonk-De Leeuw, A.M. Ovum pick up and in vitro production in the bovine after use in several generations: a 2005 status. Theriogenology 2006, 65, 914-925, doi:10.1016/J.THERIOGENOLOGY.2005.09.007.

74. Lonergan, P.; Fair, T. In vitro-produced bovine embryos: dealing with the warts. Theriogenology 2008, 69, 17-22, doi:10.1016/J.THERIOGENOLOGY.2007.09.007.

75. Tríbulo, P.; Bernal Ballesteros, B.H.; Ruiz, A.; Tríbulo, A.; Tríbulo, R.J.; Tríbulo, H.E.; Bo, G.A.; Hansen, P.J. Consequences of exposure of embryos produced in vitro in a serum-containing medium to dickkopf-related protein 1 and colony stimulating factor 2 on blastocyst yield, pregnancy rate, and birth weight. J. Anim. Sci. 2017, 95, 4407-4412, doi:10.2527/JAS2017.1927.

76. Hansen, P.J.; Dobbs, K.B.; Denicol, A.C. Programming of the preimplantation embryo by the embryokine colony stimulating factor 2. Anim. Reprod. Sci. 2014, 149, 59-66, doi:10.1016/J.ANIREPROSCI.2014.05.017.

77. Ealy, A.D.; Speckhart, S.L.; Wooldridge, L.K. Cytokines That Serve as Embryokines in Cattle. Anim. an open access J. from MDPI 2021, 11, doi:10.3390/ANI11082313.

78. Navarro, M.; Soto, D.A.; Pinzon, C.A.; Wu, J.; Ross, P.J. Livestock pluripotency is finally captured in vitro. Reprod. Fertil. Dev. 2019, 32, 11-39, doi:10.1071/RD19272.

79. Pillai, V.V.; Koganti, P.P.; Kei, T.G.; Gurung, S.; Butler, W.R.; Selvaraj, V. Efficient induction and sustenance of pluripotent stem cells from bovine somatic cells. Biol. Open 2021, 10, doi:10.1242/BIO.058756.

80. Su, Y.; Wang, L.; Fan, Z.; Liu, Y.; Zhu, J.; Kaback, D.; Oudiz, J.; Patrick, T.; Yee, S.P.; Tian, X.; et al. Establishment of Bovine-Induced Pluripotent Stem Cells. Int. J. Mol. Sci. 2021, 22, doi:10.3390/IJMS221910489.

81. Kinoshita, M.; Kobayashi, T.; Planells, B.; Klisch, D.; Spindlow, D.; Masaki, H.; Bornelöv, S.; Stirparo, G.G.; Matsunari, H.; Uchikura, A.; et al. Pluripotent stem cells related to embryonic disc exhibit common self-renewal requirements in diverse livestock species. Development 2021, 148, doi:10.1242/DEV.199901.

82. Soto, D.A.; Navarro, M.; Zheng, C.; Halstead, M.M.; Zhou, C.; Guiltinan, C.; Wu, J.; Ross, P.J. Simplification of culture conditions and feeder-free expansion of bovine embryonic stem cells. Sci. Rep. 2021, 11, doi:10.1038/S41598-021-90422-0. 